\title{
Distribution of somatostatin-immunoreactive nerve fibres in Peyer's patches
}

First Department of Anatomy and Department of Neuromorphology, Semmelweis University Medical School,

Budapest, Hungary

E Fehér

M Fodor

Department of Anatomy and Developmental Biology, University College London G Burnstock

Correspondence to: Professor G Burnstock, Department of Anatomy and Developmental Biology, University College London, Gower Street, London WC1E 6BT.

Accepted for publication 20 December 1991

\author{
E Fehér, $M$ Fodor, G Burnstock
}

\begin{abstract}
The distribution of somatostatin-immunoreactive nerve fibres in Peyer's patches of the cat was demonstrated by immunocytochemical techniques. A large number of immunoreactive nerve fibres was observed in the tela submucosa very close to the Peyer's patches. Some immunoreactive nerve cell bodies were also found in this layer. The immunoreactive nerve terminals ran around the margin of the follicles and only a few nerve fibres were observed in the centre of follicles. Electronmicroscopic investigation showed that these immunoreactive nerve terminals were in very close contact with lymphocytes and plasma cells, where no Schwann cell sheath was interposed. The gap between the nerve processes and the lymphocytes and plasma cells was about 20-200 nm, and occasionally less. These results provide morphological evidence consistent with the view that somatostatin has a neuroimmunomodulatory action. (Gut 1992; 33: 1195-1198)
\end{abstract}

It has been shown that autonomic nerve fibres are present in the different lymphoid organs. ${ }^{1-7}$ The postganglionic sympathetic noradrenergic nerves are thought to be the functional link between the immune system and the nervous system $^{89}$ and are proposed to act as neuroimmunomodulators. ${ }^{10}$ It is thought that some neuropeptides also modulate the immune function. ${ }^{11-16}$

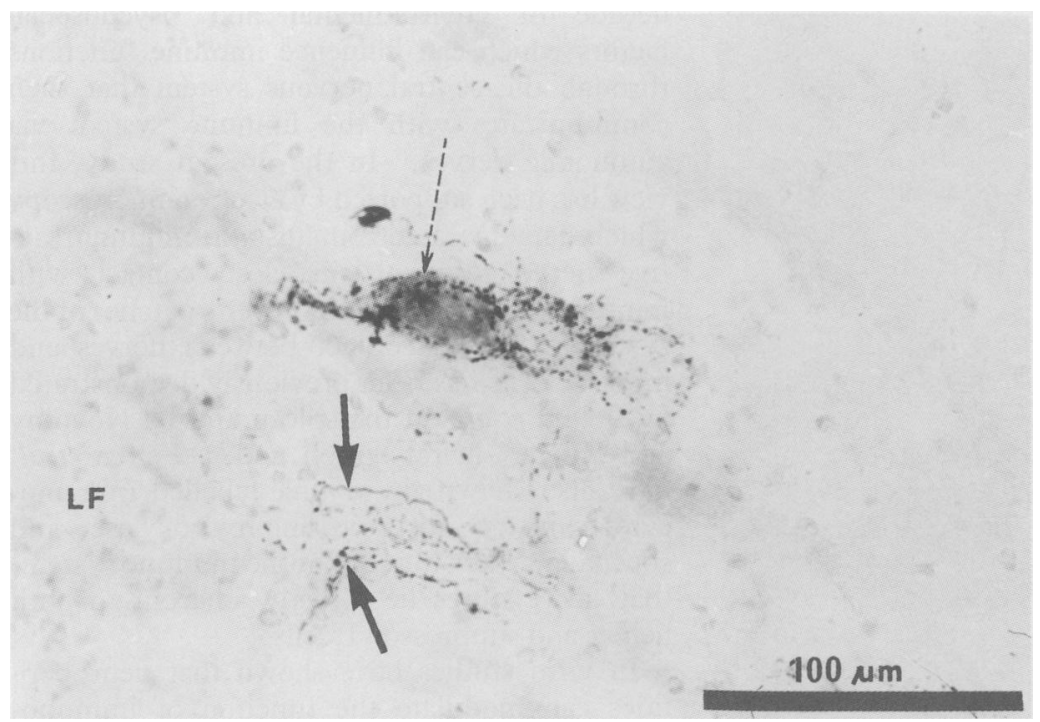

Figure 1: Somatostatin-immunoreactive nerve fibres (arrows) around the lymph follicle $(L F)$. Dotted arrow shows a somatostatin-immunoreactive nerve cell body in the tela submucosa. (Original magnification $\times 500 ;$ bar $=100 \mu \mathrm{m}$.)
Several studies in the rabbit have shown that noradrenergic sympathetic fibres innervate the gut associated lymphatic tissue - that is, Peyer's patches and the appendix. ${ }^{+17}$ Some experimental observations have suggested a possible involvement of somatostatin in immunomodulatory actions. ${ }^{18-20}$ This study aimed to determine the distribution of somatostatin-immunoreactive nerve fibres, and in particular their relation to immune cells, in the innervation of Peyer's patches of the cat, by use of immunocytochemistry at both light and electron microscope levels.

\section{Methods}

Young cats $(n=5)(1 \cdot 5-2 \mathrm{~kg})$ of either sex, kept under normal laboratory conditions, were used in this study. Before they were killed the animals were starved overnight and then anaesthetised with an intraperitoneal injection of sodium pentobarbitone $(20 \mathrm{mg} / \mathrm{kg}$ body weight). The animals were perfused transcardially with $37^{\circ} \mathrm{C}$ phosphate buffered saline (PBS) at $\mathrm{pH} 7 \cdot 3$, followed by a $4^{\circ} \mathrm{C}$ fixative containing $2 \%$ paraformaldehyde, $0 \cdot 1 \%$ glutaraldehyde, and $150 \mathrm{ml}$ saturated picric acid in $1000 \mathrm{ml}$ of Sörensen buffer ( $\mathrm{pH} 7 \cdot 3)$. After dissection, pieces of ileum were immersed in glutaraldehyde free fixative for an additional 24 hours, then rinsed for 24 hours in $0 \cdot 1 \mathrm{M}$ phosphate buffer, $\mathrm{pH} 7 \cdot 3$. The pieces were then frozen in liquid nitrogen and thawed in phosphate buffer at room temperature. Sections $(40 \mu \mathrm{m})$ were cut on a vibratome and processed according to the peroxidaseantiperoxidase technique of Sternberger et al..$^{21}$ Briefly, sections were washed in PBS and exposed to normal goat serum diluted 1:50 in PBS containing $0 \cdot 1 \%$ sodium azide for one hour at room temperature. They were then rinsed in PBS and subsequently incubated for 48 hours at $4^{\circ} \mathrm{C}$ with an antiserum to synthetic somatostatin conjugated to keyhole limpet haemocyanin (RIA, Amersham, UK) raised in rabbit, at a 1:1000 dilution.

Subsequent steps were performed on sections at room temperature as follows: sections were washed in PBS, exposed for 1.5 hours to goat anti-rabbit immunoglobulin G (IgG) serum diluted $1: 50$ in PBS containing $0.01 \%$ sodium azide, washed in TRIS buffer $(0 \cdot 1 \mathrm{M} ; \mathrm{pH} 7 \cdot 5)$, and exposed for 1.5 hours to rabbit peroxidaseantiperoxidase complex diluted 1:100 in the same TRIS buffer. After reaction with a diaminobenzidine solution (15 $\mathrm{mg}$ diaminobenzidine and $165 \mu \mathrm{l} 0.3 \% \mathrm{H}_{2} \mathrm{O}_{2}$ in $25 \mathrm{ml} 0.05 \mathrm{M}$ TRIS-HCl buffer, $\mathrm{pH} 7 \cdot 5 ; 7-8 \mathrm{~min}$ at $25^{\circ} \mathrm{C}$ ), the tissue was osmicated, dehydrated and embedded in epoxy resin (Epon). Ribbons of sections were stained with uranyl acetate and lead citrate and 


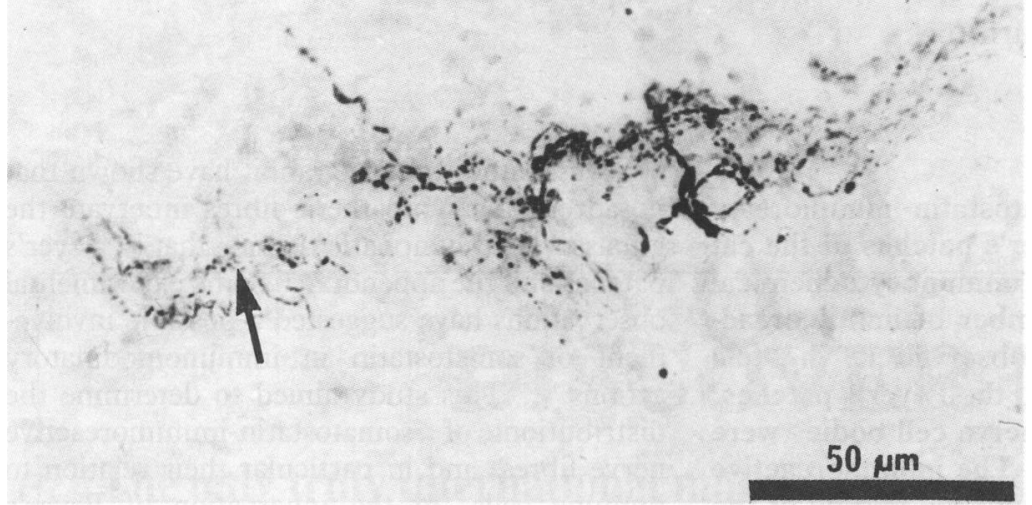

Figure 2: Somatostatin-immunoreactive nerve terminals (arrow) surrounding the lymph follicle. (Original magnification $\times 800 ;$ bar $=50 \mu \mathrm{m}$.)

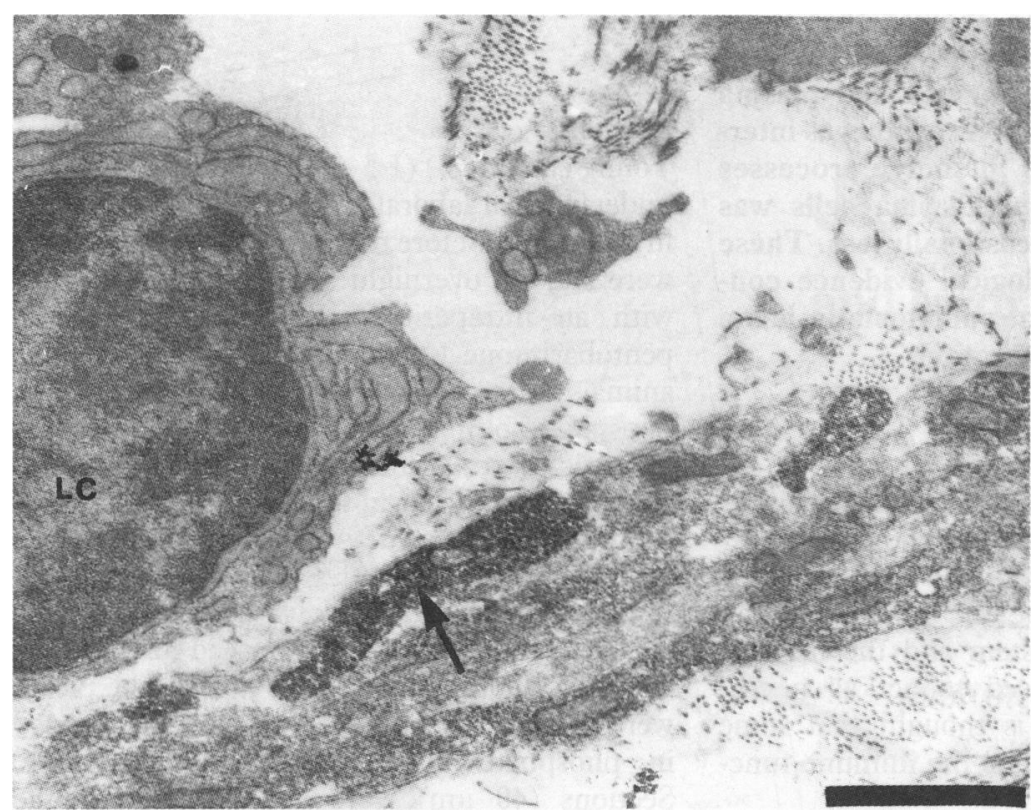

Figure 3: Somatostatin-immunoreactive nerve process (arrow), with no Schwann cell sheath, facing a lymphocyte $(L C)$. (Original magnification $\times 32000 ;$ bar $=1 \mu \mathrm{m}$.)

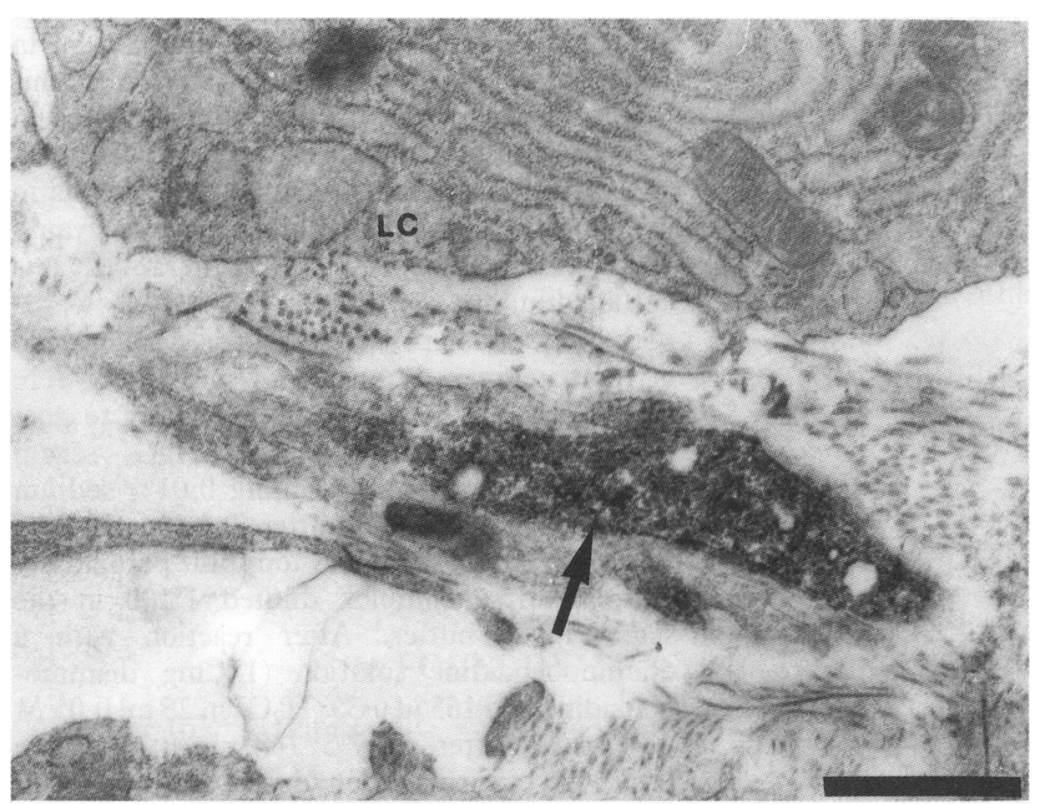

Figure 4: Somatostatin-immunoreactive nerve terminal (arrow) lying close to the lymphocyte membrane $(L C)$. (Original magnification $\times 32000 ;$ bar $=1 \mu \mathrm{m}$.) examined with a Tesla BS 300 electron microscope.

For controls, the specificity of the immunostaining was tested by preabsorption of the antiserum with synthetic somatostatin $(10 \mathrm{nmol} /$ $\mathrm{ml}$ ) for 12 hours. All specific immunostaining was blocked.

\section{Results}

Systematic light microscopic examination of serial vibratome sections showed that somatostatin-immunoreactive nerve cell bodies were located close to the Peyer's patches in the tela submucosa (Fig 1). The immunoreactive nerve fibres were observed in all layers of the ileum, not only in the region of Peyer's patches, but also in the surrounding areas, both in nerve fibres and cell bodies. A large number of them were located in close proximity to, and often surrounding, the follicles (Fig 2). These fibres were occasionally present within the follicle. However, they were numerous around the vessels at the adventitial-medial border.

When viewed with the electron microscope, the immunoreactive nerve fibres displayed homogeneous labelling. Most vesicles in the profiles were small ( $30-40 \mathrm{~nm}$ in diameter) but a few large (80-120 $\mathrm{nm}$ in diameter) dense-cored vesicles were observed among them. Most of the nerve fibres were found in very close proximity to the blood and lymph vessels. In addition they occurred as non-vascular fibres around the follicle, where they were in close association with lymphoid cells (Figs 3 and 4). In most cases the immunoreactive nerve fibres were free of Schwann cell cytoplasm, and were located close to the lymphoid cells. Sometimes they were found in direct contact with the lymphocytes and plasma cells (Fig 5). The gap between the membranes of immunoreactive nerve terminals and immunocells was $20-200 \mathrm{~nm}$, or in a few cases even less (Fig 6).

\section{Discussion}

Strong evidence has accumulated over the past decade of environmental and psychosocial factors which can influence immune functions through the central nervous system that then communicates with the immune system via autonomic nerves. ${ }^{22}$ In the present study, this view has been supported by electron microscopy which demonstrated somatostatin-immunoreactive nerve terminals in close contact with immunocompetent cells in Peyer's patches of the cat ileum. Close contact between nerves and immune cells has been previously demonstrated by Felten $e t a l^{28}$ in the spleen and by Novotny and $\mathrm{Klich}^{23}$ in rat lymph nodes. Felten et $a l^{8}$ have also shown (by double-labelled immunocytochemistry for tyrosine-hydroxylase and specific markers for cells of the immune system) that nerve fibres lie directly adjacent to both helper and suppressor $\mathrm{T}$ cells.

In vitro studies have shown that neuropeptides can modulate the function of immunocompetent cells in many ways - for example the sensory peptides substance $\mathbf{P}$ and calcitonin gene-related peptide enhance the proliferation of 


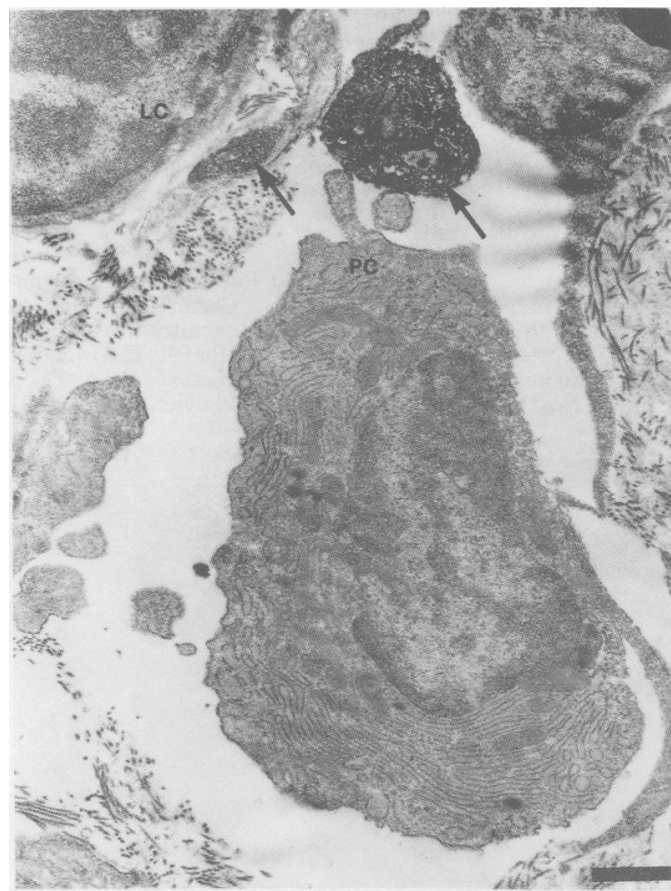

Figure 5: Somatostatin-immunoreactive nerve terminals (arrows) lie close to the lymphocyte ( $L C$ ) and in direct contact with the plasma cell $(P C)$. (Original magnification $\times 20000$; bar $=1 \mu \mathrm{m}$.)

T lymphocytes, whereas vasoactive intestinal polypeptide has opposite effects. ${ }^{2+}$ Opiate alkaloids as well as endogenous opioid peptides modify the reactions of all lymphoid cell types when administered systematically or in vitro. ${ }^{25} 26$ It has also been shown that somatostatin produces a noticeable inflammatory cell reaction ${ }^{20} 27$ as well as enhanced formation of the leukocyte

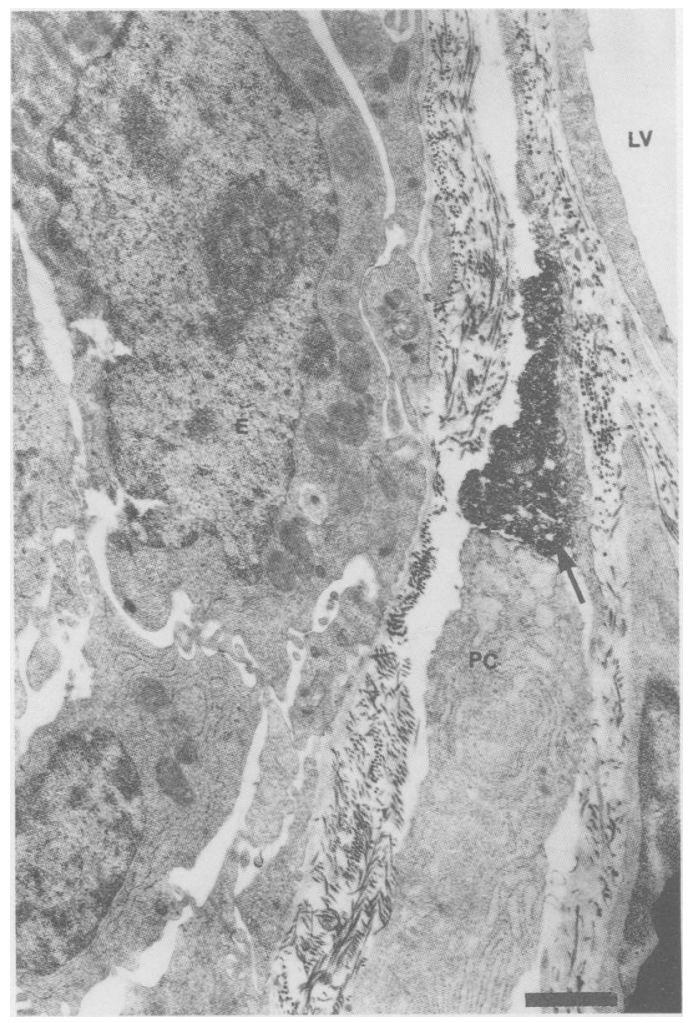

Figure 6: Arrow shows a somatostatin-immunoreactive nerve terminal in very close contact with a plasma cell $(P C)$ in the mucous membrane. LV, lymph vessel: E, epithelial cell. (Original magnification $\times 18000 ;$ bar $=1 \mu \mathrm{m}$.) migration inhibiting factor. ${ }^{19}$ It is known that either lymphocytes or plasma cells produce immunoglobulins of a single class and with unique antigenic specificity. These antibodies are released at an early stage of the response and at the very site of antigen stimulation. Therefore, it is tempting to speculate that somatostatin has similar effects when released from terminal nerve endings. This innervation may provide one channel of communication among the many neurohormonal modulations and also a direct morphological link between the nervous and immune systems.

The codistribution of somatostatin and noradrenaline in the mesenteric-coeliac ganglia ${ }^{28}$ indicates that somatostatin innervation of Peyer's patches, like other tissues, may be sympathetic. On the other hand, somatostatin has been reported in enteric neurones, ${ }^{2930}$ so some of the immunoreactive processes observed in this study may originate from that source.

1 Felten DL, Felten SY, Bellinger DL, et al. Noradrenergic sympathetic neural interactions with the immune system. Structure and function. Immunol Rev 1987; 100: 225-60.

2 Felton SY, Felten DL, Bellinger DL, et al. Noradrenergic sympathetic innervation of lymphoid organs. Prog Allergy 1988; 43: 14-36.

3 Felton DL, Felten SY, Carlson SL, Olschowaka JA, Livnat S Noradrenergic and peptidergic innervation of lymphoid tissue. F Immunol 1985; 135: 755-65S

4 Felten DL, Overhage JM, Felten SY, Schmedtje JF. Noradrenergic sympathetic innervation of lymphoid tissue in the rabbit appendix: further evidence for a link between the nervous and immune systems. Brain Res Bull 1981; 7: 595-612.

5 Giron LT, Crutcher KA, Davis JN. Lymph nodes - a possible site for sympathetic neuronal regulation of immune site for sympathetic neuronal re
response. Ann Neurol 1980; 8:520-2.

6 Lundberg JM, Ånggard A, Pernow J, Hökfelt T. Neuropeptide $\mathrm{Y}$-, substance $\mathrm{P}$ - and VIP-immunoreactive nerves in cat spleen in relation to autonomic vascular and volume control. Cell Tissue Res 1985; 239: 9-18.

7 Williams JM, Felten DL. Sympathetic innervation of murine thymus and spleen. A comparative histofluorescence study. Anat Rec 1981; 199: 531-42.

8 Felten SY, Olschowka JA, Ackerman KD, Felten DI. Catecholaminergic innervation of the spleen: are lymphocytes targets of noradrenergic nerves? In: Alan $R$, ed. Progress in catecholamine research. Part A. Basic aspects and peripheral mechanisms. New York: Liss Inc, 1988: 525-31.

9 Solomon GF. Psychoneuroimmunology: interactions between central nervous system and immune system. 7 Neurosci Res 1987; 18: 1-9.

10 Morley JE, Kay N. Neuropeptides as modulators of immune function. Psychopharmacol Bull 1986; 22: 1089-92.

11 Fink T, Norh D, Leibold A, Weihe E. Peptidergic innervation of guinea-pig lymph nodes: chemoanatomical link for sensory and autonomic neuroimmunomodulation? Neuroscience 1987; 22 (suppl): S814.

12 Fink T, Weihe E. Multiple neuropeptides in nerves supplying mammalian lymph nodes: messenger candidates for sensory and autonomic neuroimmunomodulation. Neurosci Lett 1988; 90: $39-44$.

13 McGillis JP, Organist ML, Payan DG. Substance P and immunoregulation. Fed Proc 1987; 46: 196-9.

14 O'Dorisio MS, Wood CL, O'Dorisio TM Vasoactive intestinal peptide and neuropeptide modulation of the intestinal peptide and neuropeptide modulation

15 Ottaway CA, Greenberg CR. Interaction of vasoactive intestinal peptide with mouse lymphocytes. Specific binding and the modulation of mitogen responses. F Immunol 1984; 132: 417-23.

16 Payan DG, Goetzl EJ. Modulation of lymphocyte formation by sensory neuropeptides. F Immunol 1985; 135: 783-6S

17 Jesseph JM, Felten DL. Noradrenergic innervation of the gut associated lymphoid tissues (GALT) in the rabbit. Anat Rec 1984; 208: 81A

18 Pawlikowski M, Stepien H, Kunert-Radek J, Schally AV. Effect of somatostatin on the proliferation of mouse spleen
lymphocytes in vitro. Biochem Biophys Res Commun 1985; 129: 52-5.

19 Pawlikowski M, Zelazowski P, Stepien H, Schally AV. Somatostatin and its analog enhance the formation of human Somatostatin and its analog enhance the formation of human immunomodulatory action of somatostatin. Peptides 1987; 8: $951-2$.

20 Sandkühler Q, Fu G, Helmchen C. Spinal somatostatin superfusion in vitro affects activity of cat nociceptive dorsal horn neurons: comparison with spinal morphine. Neuroscience 1990; 34: 565-76.

21 Sternberger LA, Hardy PH, Cuculus JL, Meyer HG. The unlabelled antibody enzyme method of immunohisto- 
chemistry. Preparation and properties of soluble antigenantibody complex (horseradish peroxidase-antihorseradish peroxidase) and its use in identification of spirochetes. peroxidase) and its use in identification
$\exists$ Histochem Cytochem 1970; 18: 315-33.

22 Ader R, Cohe N, Felten DL. Brain, behaviour and immunity. Brain Behav Immunol 1987; 1: 1-6.

23 Novotny GEK, Kliche KO. Innervation of lymph nodes: combined silver impregnation and electron-microscopic study. Acta Anat 1986; 127: 243-8.

24 Payan DG, McGillis JP, Renold FK, Mitsuhashi M, Goetz EJ. Neuropeptide modulation of leukocyte function. Ann NY Acad Sci 1987; 496: 182-91.

25 Jankovic BD, Maric D. Modulation of in vitro immune responses by enkephalins. Clin Neuropharmacol 1986; 9: respons 8 .

26 Wybran J. Enkephalins and endorphins as modifiers of immune system: present and future. Fed Proc 1985; 44: 92-4.
27 Mollenholt P, Post C, Rawal N, Freedman J, Hökfelt T, Paulsson I. Antinociceptive and 'neurotoxic' actions of somatostatin in rat spinal cord after intrathecal administration. Pain 1988; 32: 95-105.

28 Costa M, Furness JB. Somatostatin is present in a subpopulation of noradrenergic nerve fibers supplying the intestine. Neuroscience 1984; 13: 911-9.

29 Fehér E, Léránth C, Gallatz K. Somatostatin immunoreactive nerve elements in the rat small intestine: light and electron microscopic studies. Acta Morphol Hung 1986; 34: 59-71.

30 Furness JB, Llewellyn-Smith IJ, Bornstein JC, Costa M. Chemical neuroanatomy and the analysis of neuronal
circuitry in the enteric nervous system. In: Björklund A, Hökfelt T, Owman C, eds. Handbook of chemical neuroanatomy. Vol 6. The peripheral nervous system. Amsterdam: anatomy. Vol 6. The periph

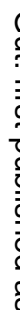

